\title{
COVID -19 Gateway for ICT Integration; The case of St. Dominic Hospital, Akwatia
}

\author{
Article by Ebenezer Kenneth Abban \\ Healthcare Administration, Texila American University, Akwatia, Ghana \\ E-mail:kwakuabban@gmail.com
}

\begin{abstract}
The application of Information and Communication Technology during these times of Covid-19 has been phenomenal. For example, the number of people who use zoom, an ICT application, during this time of covid-19 has increased by over 1000\%. This study examines the extent to which ICT integration at St. Dominic Hospital would be necessary to provide quality care to patients without compromising the expectation of the latter. Descriptive analysis of data is employed to analyze $(n=78)$ staff. $64 \%$ of respondents will not visit the hospital during this time for fear of contracting the infection of SARSCov-2, although $41 \%$ will still prefer face-to-face interaction with a prescriber than interaction over the internet. The study utilizing time series analysis demonstrates an increase of $4.7 \%$ in admission rate without integration of ICT with OPD visits seeing a downward trend. Nonetheless, $58 \%$ of respondents share the view that ICT integration is needful during this time of Corona Virus.
\end{abstract}

Keywords: Covid-19; SARS-CoV-2; World Health Organization (WHO); Information and Communication Technology; United Nations Development Programme (UNDP); St. Dominic Hospital, Akwatia.

\section{Introduction}

SARS-CoV-2 pandemic (Covid-19), by and large, has significantly changed the healthcare landscape at an unprecedented rate. The virus arguably has impacted the very fabric of society and human life since $11^{\text {th }}$ March, 2020 when the World Health Organization announced that Covid-19 had escalated to pandemic levels (WHO, 2020). Although the world has been in a response mode with urgent and aggressive actions since the virus escalated to pandemic levels, the effect of the virus on society and human life has been quite extensive and keeps rampaging with no end immediately in sight. Experts have rendered covid-19 not only a public health crisis but also one that has touched every sphere of human life, thus the World Health Organization right from the beginning invited countries to take a "whole-of-government, whole-of-society approach, built around a comprehensive strategy to prevent infections, save lives and minimize impact" (WHO, 2020). Under this dispensation, every government, on the face of the earth, is observed taking heed to the advice of the World Health Organization and efforts are seen to be made by many to bring the virus under control.

Even though the virus has largely impacted almost all economies of countries and in fact every industry one can imagine, its effect on the healthcare industry is without doubt extremely huge. Thomas Lee, MD, for Brigham \& Women's Hospital in Boston, and the chief medical officer for Press Ganey, USA, retorted this is one of the most stressful periods of all time for the healthcare industry in his many years of practice (Sara Heath, 2020). Several issues ranging from shortage of personal protective equipment's; refusal of patients to visit hospital early for attention; inadequate numbers of healthcare workers to proportionally cater for large numbers of severely ill patients suspected of covid-19 infection; delays in receiving results of samples of suspected cases of covid-19; unavailability of life-support medical equipment i.e. ventilators; and financial resources coupled with ensuring one of the essential covid-19 protective protocols of social distancing between healthcare givers and patients have been among many critical concerns that healthcare providers have had to battle with during the Covid-19 pandemic times. In the view of the United 
Nations Development Programme (UNDP), chronicled in a scientific work, there is no doubt that the Corona virus pandemic has gravely wounded health systems and it is the "defining global health crisis of our time" and the greatest challenge the world has faced after World War Two (UNDP, 2020).

The circumstances as currently presented during this era of Covid-19, with its attendant social distancing protocol, information and communication technology has retooled the world, especially in, social gatherings, religious assemblies, government engagements, financial services, educational engagements and healthcare provision. According to Kate O'Flaherty (April, 2020), a senior cyber security journalist, prior to the SARS-CoV-2 crisis, many people had not even heard of video conferencing application Zoom. Nonetheless, the user base of this ICT application has significantly surged from about 10 million last year (2019) to about 200 million as at April, 2020. In fact, currently, people are using it for several activities which hitherto was not applied to but probably mainly by businesses. Currently, at least since the announcement of covid-19 as pandemic by WHO, on the healthcare landscape in particular, the pandemic has opened the way for substantial adoption and application of ICT in the area of telehealth. Zoom for example has been reliably used to support healthcare teams and patients around the globe for consistent and credible delivery of clinical experiences by high quality video, even in lowbandwidth environments (zoom homepage, 2020). The story, as thus told, is quite different at St. Dominic Hospital, Akwatia and not much of ICT has been applied to the delivery of healthcare during the era of covid-19. Factors such as, economic, socio-cultural, technological, educational and medical condition, of the patient mix of the hospital are interrogated in this study to understand what really the issues are.

\section{Background}

In December, 2019, the World Health Organization, China Country Office, was informed by the authorities of China of pneumonia of unknown cause, detected in the city of Wuhan in Hubei province, China. This had been found among some patients in the Huanan Seafood market. According to the WHO, infection with SARS-CoV-2 primarily causes respiratory illness ranging from mild disease to severe disease and death, and some people infected with the virus never develop symptoms. Fast forward, China shares the genetic sequence of the novel corona virus, which will be very important for other countries as they develop specific diagnostic kits. It was not a surprise to have an official confirmation of a case of the novel corona virus in Thailand thus WHO calls for active preparedness and monitoring by all countries in this regard and sooner than later, in March, 2020, the World Health Organization had announced that the Covid-19 had taken a pandemic levels (WHO, 2020).

The World Health Organization (WHO) constantly offers briefing to Member countries and the general public on the SARS-CoV-2 pandemic related issues and especially on infection prevention and control matters given that transmission and infection rate continue to escalate world over. In the scientific brief of July $9^{\text {th }}, 2020$, WHO presented an "overview of the modes of transmission of SARS-CoV-2, what is known about when infected people transmit the virus, and the implications for infection prevention and control precautions within and outside health facilities". A number of modes underlined for the spread of the virus include contact, droplet, airborne, fomite, fecaloral, bloodborne, mother-to-child, and animal-tohuman transmission (WHO, 2020). The scare of the virus surges given that no vaccines have been found and the number of infections keep increasing by the day. Ghana for example as of March $12^{\text {th }}, 2020$ had recorded two confirmed positive cases and within a space of four months had recorded a total confirmed positive case of 23,834 (GHS, 2020).

\section{Information and Communication Technology (ICT)}

The use of information and communication technologies (ICT) is fundamentally an integral part of modern society. Information is regarded as a valuable asset for all individuals and organizations and this information needs to be communicated; technology therefore becomes one of the means by which this is done causing rapid transformation of all spheres of life (World Youth Report, 2003). Yekini Nureni Asafe (2014) identifies Information and Communication Technology (ICT) as the convergence of audio-visual, telephone and computer networks via link system and with the 
vision to successfully accomplish a set objective or goal either by an individual or an organization.

Many people have a firm belief and conviction that ICT is one of the key pillars reengineering economic growth and financial development leading into the next century. Ewa Lechman, Adam Marszk (2019), shared the view that the landscape of the new era shall broadly be shaped by ICT for financial development in the areas of financial markets, stock markets, bond markets, exchange-traded funds among others. Given the current scheme of society, the possibility of new inventions enveloping the space of technology in greater proportion could only be anticipated. Shenzhen, Pudu Technology Co., Ltd as at today $(15 / 07 / 2020)$ has developed technology to manufacture several types of robots to serve different purposes.

\section{Corona Virus (Covid-19)}

It is a member of a large family of viruses that cause illness ranging from common cold to more severe diseases such as Middle East Respiratory Syndrome (MERS-CoV) and Severe Acute Respiratory Syndrome (SARS-CoV). SARSCoV-2 is the virus; highly contagious. Although this kind of infection (the family of upper respiratory tract infections including otitis media) is usually mild and self-limiting, sometimes it could lead to highly complicated conditions that can be life threatening (Peter S. Morris, 2009). It is limited human to human transmission; predominantly nosocomial (MERS > SARS) and viral replication in the lower respiratory tract (CDC, 2020). The risk of infection is highly dependent on exposure and its spread is highest amongst close contacts of infected persons via human-to-human transmission, droplets (coughing and sneezing), close personal unprotected contact with an infected person (touching, shaking hands), contact with contaminated fomites e.g. door handles, surfaces (GHS, 2020).

The four key steps currently used in the management of the SARS-CoV-2 are, Identify, Isolate, Notify, and Support. Currently, there are no documented therapies on treatment of the virus. Nonetheless, infected people are offered needful randomized controlled trial (RCT).

\section{St. Dominic Hospital, Akwatia}

St. Dominic Hospital has been serving the Denkyembuor District and its environs with care and compassion since 1960. The core foundation of the Hospital runs on the implementation of a ten-year strategic plan under the guide of the mission, vision and values of the hospital. Its vision is to be "a health service that is best in meeting patients' needs and expectations". The mission on the other hand is "to provide high quality healthcare in the most effective, efficient and innovative manner, specific to the communities we serve and at all times acknowledging the dignity of the patient". In pursuing this mission, the hospital embodies the Christian principles of health care in a Catholic tradition hence the following core values: (1) God fearing - human life is sacred and inviolable in all spheres of existence and in every situation. Reverent feeling towards God is a necessity. (2) Honesty - truthfulness must prevail under every circumstance. (3) Professionalism - quality of care, work life, education and research should always be in focus. (4) Supportiveness - the quality of presence and caring that accepts people as they are and fosters healing and wholeness must exist at all times. (5) Accountability promotion of the just use of resources entrusted to people for the enhancement of human life. (6) Innovativeness - the translation of ideas into services and inventions that benefit humanity. (7) Integrity - the quality of having strong moral principles and (8) Respectfulness - each person as a unique individual with a right to be respected and accepted (SDH, 2020). The effects of the pandemic clearly show in the numbers of the Hospital as presented in the figures below with a certain trend. Out patients numbers went down in 2020 over the same period in 2019. New patients did not show any significant difference in trend. On the other hand, many patients were admitted on the Wards in 2020 over the same period in 2019. The number of deaths escalated within the period. The assumption is that, these were not ordinary times and certainly covid-19 pandemic had extensive impact on the provision of care during the era under study.

\section{Methodology}

\section{Study type}

The study was an application of both descriptive and inferential statistics in a crosssectional research. A randomly selected number of staff of St. Dominic Hospital was engaged in this work. Besides this, docs.google.com was employed to further engage additionally selected 
staff who could not answer the paper questionnaire.

\section{Population and sample}

The study population was single based. It was mainly the staff of St. Dominic Hospital that was used for the work. A total of seventy-eight staff was sampled for the study and all of them answered the questionnaire. 44 respondents, representing $56.4 \%$, were females, while 34 respondents were males, representing $43.6 \%$.

\section{Data collection}

Staff of St. Dominic Hospital formed the primarily data base of the study. Given the current arrangements of staff deployment for work, fifty-eight of the staff answered the questionnaire by docs.google.com and twenty staff responded through hard paper questionnaire. A self-administered module questionnaire was engaged in this exercise. Although both qualitative and quantitative methods of data collection were applied, much emphasis was rather put on the latter.

\section{Data analysis}

\section{Variables measurement}

The dependent $(\mathrm{Y})$ variable of the study was ICT integration. There were five independent (X) variables for this study namely; economic status (financial strength); socio-cultural background; educational background; medical condition; and technological background. Each of the independent variables was measured by the extent of its effect on ICT integration as the dependent variable using St. Dominic Hospital as the setting.

\section{Results and Discussions}

This study demonstrates an increase of $4.7 \%$ in admission rate between 2019 and 2020 using time series analysis. A direct consequence of SARS$\mathrm{CoV}-2$ is possible for the difference. It could further indicate that there were patients who did not visit hospital on time during the pandemic and waited for the health condition to move from moderate to severe before reporting to hospital and thus were admitted. This could be inferred because conversely the out patients numbers went down by $3.9 \%$.

$58 \%$ of the respondents believed that employing ICT during the era of Covid-19 was needful. However, only $12 \%$ of the respondents were of the view that a patient needs to be educated to be able to utilize ICT for the purposes of seeking care. This notwithstanding, 41\% would prefer face-to-face interaction with a prescriber than over an internet interaction with same. Alternatively, the fear of contracting infection of the virus on a hospital environment was $64 \%$ among the respondents. Although 63\% of the staff sampled shared the view that a patient social status was necessary for accessing ICT, the cultural background of such persons was irrelevant when it came to the use of ICT to access care.

Limitations of this study include the singlestage setting; small numbers of respondents; short time frame; and the unwillingness of staff to participate in the study. Moreover, a comparable period of 2019 was used for the time series analysis, but this should not affect the results as the researcher intended 2019 for the benchmark.

\section{Conclusion}

The necessity of ICT integration into the delivery of care during Covid-19 pandemic times is undisputed by this study. Although the advent of SARS CoV-2 has brought to lime light a number of innovations in the information and communication technology landscape in a much faster and impressive manner, one of which is telehealth, this studies has demonstrated to a large extent that a good percentage of the staff of St. Dominic Hospital, Akwatia, would still prefer a face-to-face treatment by a prescriber than over the internet interaction. Moreover, the study shows that over $64 \%$ of the staff is of the view that, visiting the Hospital could expose patients to contracting infection of the virus. The irony, therefore, is that it will take only ICT integration to avoid physical visit to the hospital. 


\section{Figures}

OPD ATTENDANCE $2011-2020$

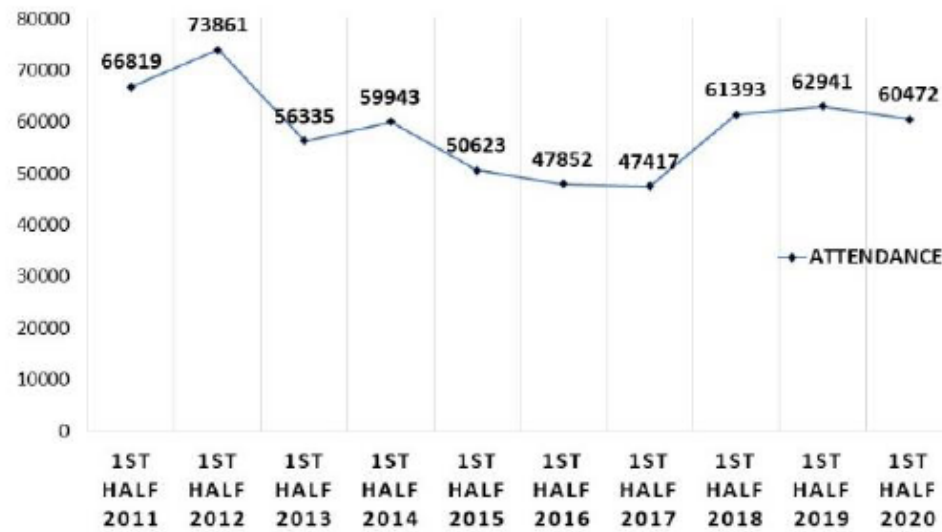

Figure 1. Source - field work

TRENDS OF ADMISSION 2011 - 2020

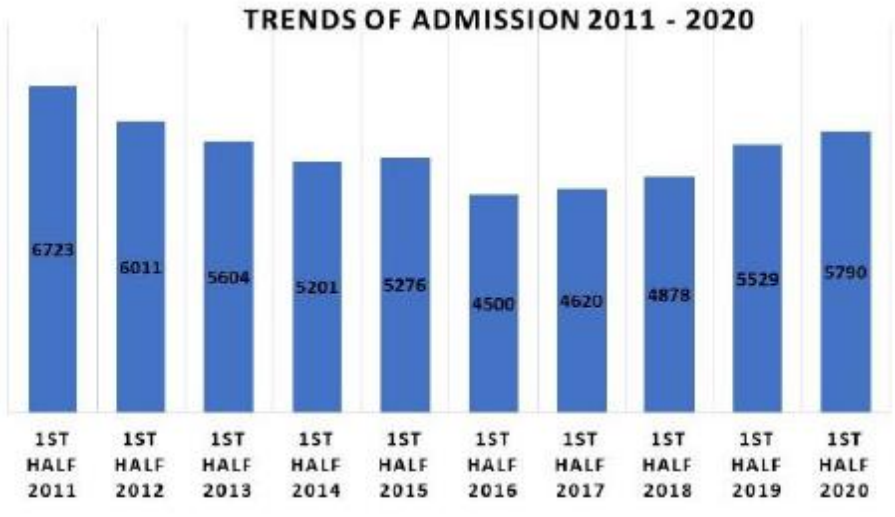

Figure 2. source - field work

Table 1. Source - field work

\begin{tabular}{|l|l|l|l|}
\hline \multicolumn{4}{|l|}{ Summary of Admissions 2017-2019 } \\
\hline Indicator & 2018 & 2019 & 2020 \\
\hline Total Admissions & 4878 & 5529 & 5790 \\
\hline Deaths & 158 & 132 & 217 \\
\hline
\end{tabular}

TOTAL NEW PATIENTS ATTENDANCE 2011 - 2020

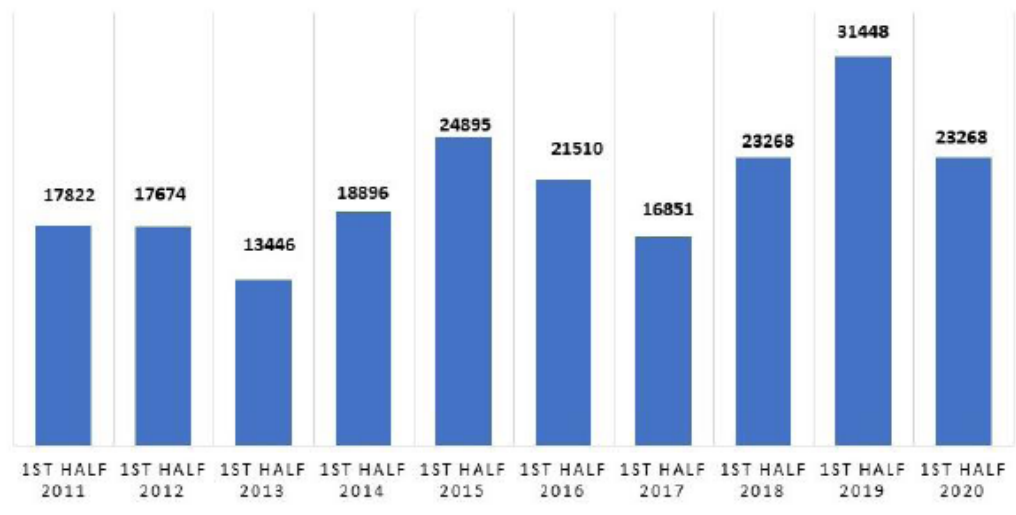

Figure 3. Source - field work 


\section{References}

[1]. CDC, 2020, Interim Guidelines for COVID-19 Antibody Testing in Clinical and Public Health Settings, available at

https://www.cdc.gov/coronavirus/2019-

ncov/lab/resources/antibody-tests-guidelines.html, retrieved on 13/07/2020

[2]. Ewa Lechman, Adam Marszk (2019), ScienceDirect Journal, ICT-Driven Economic and Financial Development, available at https://doi.org/10.1016/B978-0-12-813798-7.00006-

3 , retrieved on $18 / 07 / 2020$

[3]. GHS, 2020, Covid-19 update, available at https://ghanahealthservice.org/covid19/, retrieved on $10.07 / 2020$.

[4]. GHS, 2020, About Covid-19, available at https://ghanahealthservice.org/covid19/about.php, retrieved on 13/07/2020.

[5]. Kate O'Flaherty (April, 2020), zoom: here's when to use it and when you should avoid it, available at https://www.forbes.com/sites/kateoflahertyuk/2020/0 4/15/zoom-during-covid-19-heres-when-you-shoulduse-it-and-when-to-avoid-it/\#131f33eb376e, retrieved on $15 / 07 / 2020$.

[6]. Peter S. Morris, 2009, Upper Respiratory Tract Infections (Including Otitis Media), journal pediatr clin N Am 56 (2009) 101-117, Published by Elsevier Inc.

[7]. Sara Heath, 2020, How Will COVID-19 Change Patient Experience, Healthcare Delivery? at https://patientengagementhit.com/news/how-willcovid-19-change-patient-experience-healthcaredelivery, retrieved on 10/07/2020.
[8]. SDH, 2020, Mission, vision and core values, available at sdhakwatia.org, retrieved on 10/07/2020 [9]. Shenzhen, Pudu Technology Co., Ltd (2020), The best ever delivery robot is here, available at https://www.pudutech.com/, retrieved on 16/07/2020. [10]. UNDP, 2020, Covid-19 Pandemic; humanity needs leadership and solidarity to defeat the corona virus, available at

https://www.undp.org/content/undp/en/home/coronav irus.html, retrieved on 12/07/2020

[11]. WHO, 2020, Timeline of WHO's response to COVID-19 at https://www.who.int/newsroom/detail/29-06-2020-covidtimeline, retrieved on $10 / 07 / 2020$

[12]. WHO, 2020, Transmission of SARS-CoV-2: implications for infection prevention precautions.

[13]. Yekini Nureni Asafe (2014), Information Communication Technology (ICT) [Concepts and Application], Hasfem Publication Center, Shomolu, Lagos, Nigeria.

[14]. World Youth Report (2003), Youth and Information and Communication Technology (ICT), available

at https://www.un.org/esa/socdev/unyin/documents/ch1 2.pdf, retrieved on 16/07/2020

[15]. Zoom homepage, 2020, Video Conferencing for telehealth, available at https://zoom.us/healthcare, retrieved on $15 / 07 / 2020$ 